\section{Geologic Approaches to the Determination of Long-Term Coastal Recession Rates, Matagorda Peninsula, Texas}

\author{
B. H. Wilkinson
}

Department of Geology and Mineralogy, The University of Michigan Ann Arbor, Michigan 48109, U.S.A.

\section{J. H. McGowen}

Bureau of Economic Geology, The University of Texas

Austin, Texas 78712 U.S.A.

ABSTRACT / The degree to which human modifications in the coastal zone have increased or decreased coastal erosion rates is difficult to determine owing to the short time period for which shoreline-position data are available. This limitation is circumvented in areas where long-term recession rates can be determined from geologic data. Three such areas from Matagorda Bay have been examined to determine the temporal variation in recession rates over the past several thousand years. Preliminary results indicate that recession rates over the past century may be $30 \%$ to $40 \%$ greater than those of prehistoric time. Although additional data are needed, it is suggested that accelerated rates result from human modification of the coastal $20 n e$, and that in the future increased recession rates can be anticipated.

\section{Introduction}

Shoreline erosion and recession represent a serious environmental problem in the Texas Coastal Zone. Understanding of the processes responsible for shoreline recession depends not only on analysis of the lateral variation in recession rate but also on an analysis of the temporal variation of rate for any specific area. Recession rates commonly are determined through comparison of a chrononological sequence of charts, maps, and/or aerial photography. Determination of the temporal variation of rate with such data are limited by the short time period over which measurements are taken. In many cases, accurate coastal charts are available for only a century or so, and aerial photographs are available for only a few decades. As a result, the use of historical data for analysis of variation of recession rates in most areas is limited.

McGowen and Brewton (1975) examined historic shoreline changes in the Matagorda Bay area, Texas. They indicated that between 1856 and 1957 erosion was a natural process along the Gulf shoreline and that erosional shoreline trends were established at least 118 years ago before any significant modification of the coastal environment by man. Given their data on historic recession rates, one may then question whether the rates of erosion determined reflect natural conditions or if they have been significantly accelerated or decelerated by the activities of man. Comparison of long-term recession rates (encompassing several millenia) with short-term recession rates (several decades) along three sections of Matagorda Peninsula provides a temporal context in which the short-term data can be evaluated.

\section{Geological Setting}

Matagorda Peninsula is a narrow barrier [peninsula] which separates Matagorda Bay from the Gulf of Mexico (Fig. 


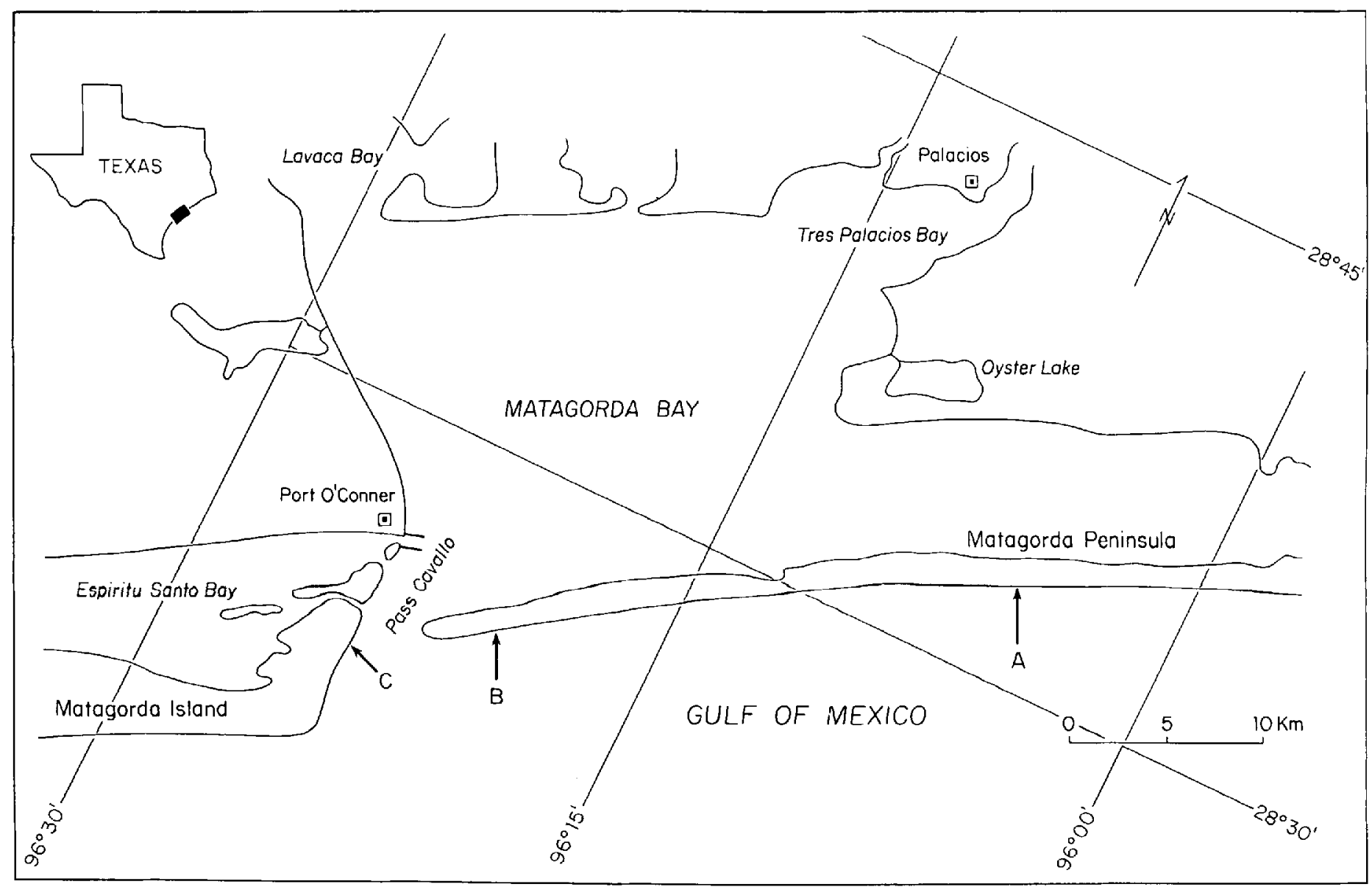

1). This segment of the coast has been migrating landward for several thousand years. Shoreline recession is a result of daily removal of sediment along the beach by waves and transport of sediment bayward into Matagorda Bay during hurricanes. Numerous hurricane surge channels, which cross the peninsula normal to the Gulf shoreline, attest to the frequency of this catastrophic process. Matagorda Peninsula is a sand body that overlies older bay muds which accumulated in Matagorda Bay. These muds have been overridden progressively by the peninsula during its landward retreat. Bay muds in turn overlie an irregular surface developed on Pleistocene sediments which were weathered and dissected during the Wisconsin lowstand of the Gulf of Mexico.

Most of Matagorda Peninsula is in an erosional state and has been so for many decades. This is due to several processes described by McGowen and Brewton (1975) which include: (1) a deficit of sand-size material made available to littoral currents from erosion of shelf and shoreface sediments and from rivers to the northeast, and (2) human activities such as construction of dams across major fluvial systems, rice farming adjacent to major streams which requires large volumes of water, construction of jetties, and river diversion. Analysis of the relative importance of these factors is possible through the determination of temporal variation in erosion and reces. sion rates.

\section{Central Matagorda Peninsula}

Recession rates spanning a 900-year period can be estimated for Central Matagorda Peninsula. In this area the subaerial vegetated barrier is separated from the subaquaeous muds of Matagorda Bay by a broad, flat, sand platform which extends from the lagoonward margin to water depths of 1 meter. This platform terminates abruptly as water depths increase to nearly $3 \mathrm{~m}$; bay muds accumulate at these depths (Fig. 2). Shoreline retreat in this atea is accomplished primarily during the passage of hurricanes when the beach and shore- 
Figure 1. Matagorda Bay Area. Arrows indicate areas discussed in the text. (a) Central Matagorda Peninsula area; (b) Southwestern Matagorda Peninsula area; (c) Pass Cavallo area.

face are eroded, and sediment is transported into the adjacent bay. During these brief but high energy events, the entire peninsula migrates bayward. The bayward margin of the sand platform represents the landward limit of sediment transport during these events.

An estimate of long-term recession

Figure 2. Dip section across central Matagorda Peninsula showing the distribution of barrier sands and bay muds. Shell of Crassostrea collected from a reef penetrated at a depth of $6 \mathrm{~m}$. Dashed isochronous lines indicate bayward accretion of sand and shell resulting from storm surges. rates can be made for a part of Matagorda Peninsula utilizing a radiocarbon age determination of $900 \pm 30$ years B.P. from Crassostrea virginica (the edible oyster) recovered from bay mud just below the sands which make up the barrier. The age of the oysters closely approximates the time when sediment derived from the shoreface and beach of the peninsula was transported across the barrier to accumulate in the area (Fig. 3). The horizontal distance between the hole from which this material was recovered and the present bay margin and platform edge are known. Since the width of this platform is fairly constant throughout this area, the rate that Mata- gorda Peninsula accreted over bay muds can be estimated. These data indicate that average recession rates for Matagorda Peninsula in this area have been approximately $0.9 \mathrm{~m} /$ year for the past 900 years.

In deriving this estimate, two assumptions have been made: (1) the rate of sediment accretion on the bayward edge of the sand platform closely reflects the rates of Gulf shoreline erosion, and (2) the oyster reef grew on the bay bottom fairly close to the edge of the baymargin sand platform, and the time of burial by bayward accretion is closely reflected by the age of these shells. Neither assumption can be conclusively

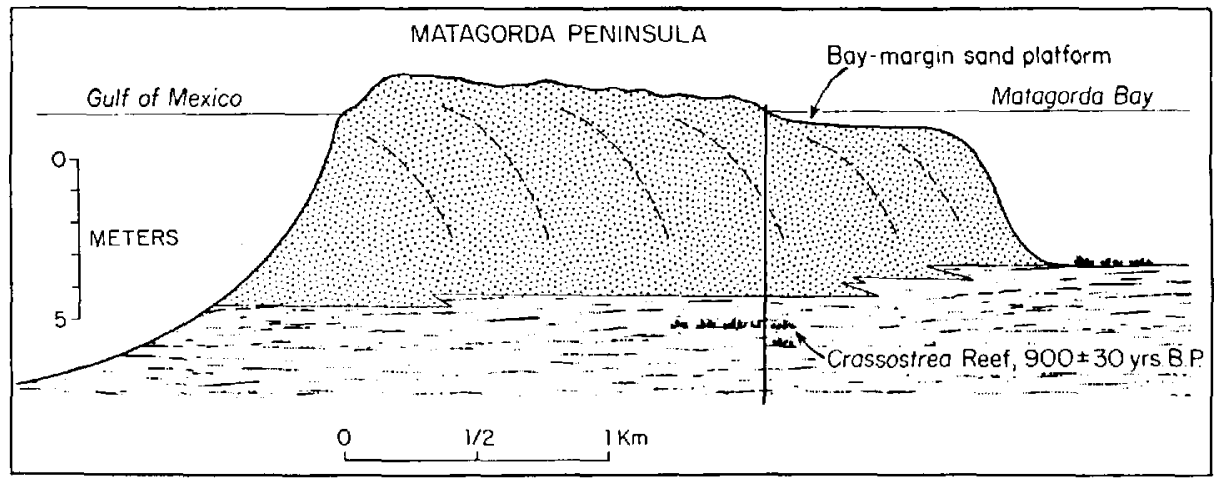

Figure 3. Distribution of the subaerial barrier, bay-margin sand platform, and deeper mud-bottom bay along Central Matagorda Peninsula. Long-term recession rate calculated by dividing the horizontal distance between the sample hole and the sand platform margin by 900 years. Short-term recession rate from McGowen and Brewton (1975).




Figure 4. Development of an erosional unconformity on eastern Matagorda Island. (a) Closing of the tidal pass (Pass Cavallo) by deposition on the flood delta; (b) Tidal pass closed, erosion smoothes the Gulf shoreline by removal of part of eastern Matagorda Island; (c) Pass Cavallo as it appears today, following reopening of the tidal pass, erosion of the flood delta by waves in Matagorda Bay, accretion of eastern Matagorda Island, and bayward retreat of Matatorda Peninsula. Dashed line represents the position of the Gulf shoreline 1500 years B.P. Modified from McGowen and Brewton (1975).

defended, but several lines of reasoning suggest that they are warranted.

In order to estimate long-term recession rates, net bayward accretion must be the same as net erosion on the beach and shoreface. Matagorda Peninsula exhibits little variation in the width of the bay margin sand platform, or in the width of the subaerial barrier. This requires that the long-term variations in both shoreline erosion and bayward accretion are insignificant laterally. If longterm coastal erosion was variable along the Gulf shoreline, the beach would not be straight, nor would the width of the subaerial barrier be constant. Similarly, if rates of bayward accretion were laterally variable, the landward margin of the bay margin platform would not be straight, nor would the width of this platform exhibit a laterally uniform width. As a result, long-term rates of Gulf erosion and bayward accretion must be laterally similar. If accretion rates and erosion rates for this segment are dissimilar, this must be reflected in a long-term change in the combined widths of the subaerial and subaquaeous peninsula. Although this possibility cannot be directly evaluated, the uniformity of width along the peninsula's entire length, and the close agreement between calculated accretion rates behind central Matagorda Peninsula and shoreline recession rates estimated for southwestern Mata-

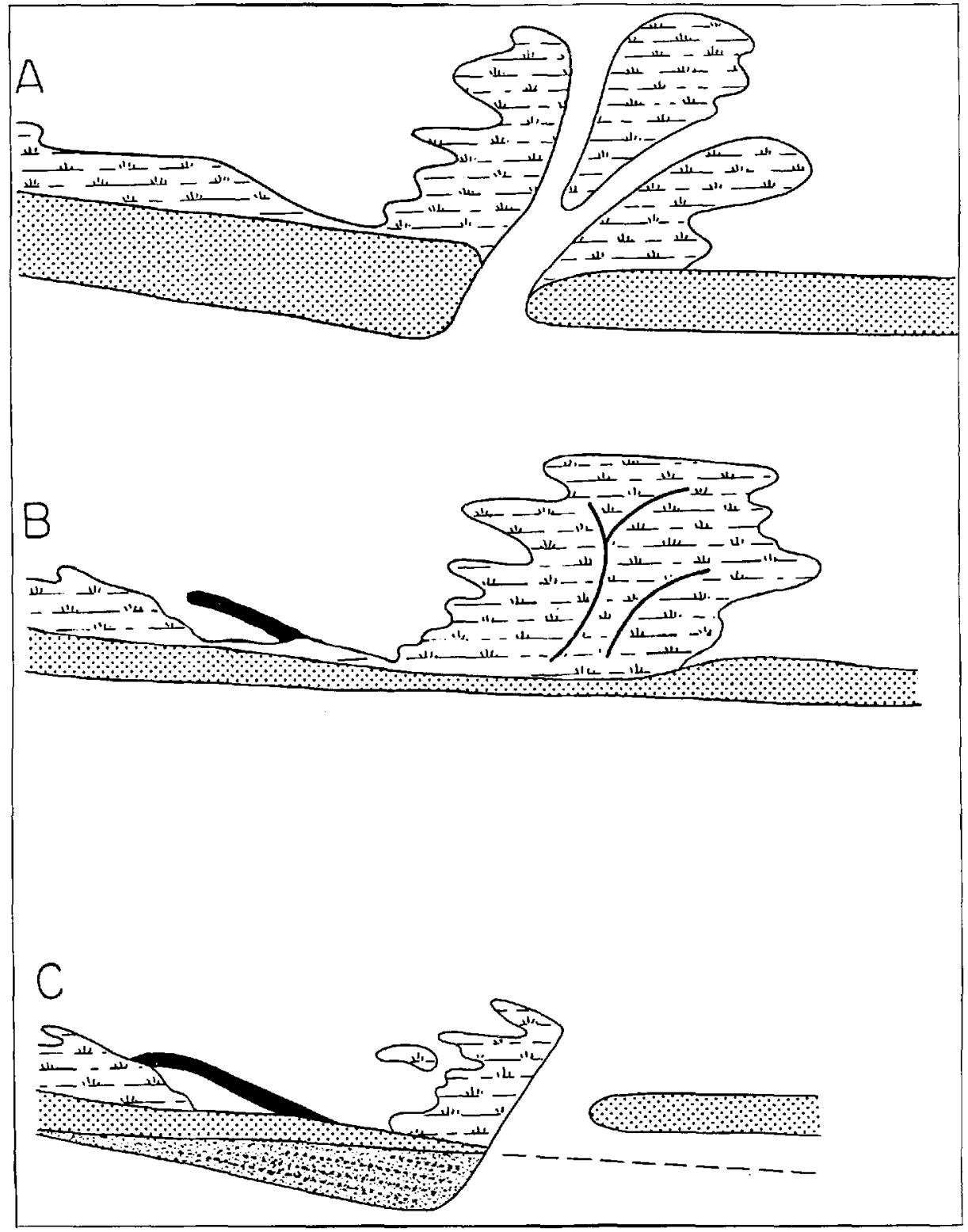

gorda Peninsula suggest that this is probably not the case.

The possibility that the Crassostreo reef grew some distance from the edge of the bay margin platform and that it is considerably older than the overlying sands also cannot be directly evaluated. Shell material was collected from a $1-\mathrm{m}$ zone beneath the base of the barrier sands. If this reef were significantly old-
Figure 5. Estimated recession rate for Southwestern Matagorda Peninsula. Long-term rate calculated by dividing the horizontal distance between the Gulfward projection of the unconformity along Matagorda Peninsula, and the present position of the Gulf shoreline of Matagorda Peninsula by 1,500 years. Short-term recession rate from McGowen and Brewton (1975). 
er than the sands which buried it, one would anticipate the presence of some [thickness of] bay mud overlying the reefal mass. Data on rates of argillaceous sedimentation in this area are few; however, Shepard and Moore (1960) reported rates of $1.07 \mathrm{~m} /$ century for mud deposition in this part of Matagorda Bay. If a maximum thickness of $1 \mathrm{~m}$ of mud separates this reef from the overlying sands, calculated bayward accretion rates would be too rapid by only $11 \%$ or 0.1 $\mathrm{m} /$ year. We believe that the uncorrected recession rate of $0.9 \mathrm{~m} / \mathrm{year}$ is more accurate.

Short-term recession and erosion rates for this segment of Matagorda Peninsula are highly variable. Shepard (1973) reported that as much as $244 \mathrm{~m}$ of shoreline recession occured in this area during the passage of hurricane Carla in 1961. McGowen and Brewton (1975) reported that this same area had accreted as much as $154 \mathrm{~m}$ between 1961 and 1971 (this is $90 \mathrm{~m}$ short of the pre-Carla shoreline position). Clearly, severe storms cause high variation in short-term accretion and recession rates.

McGowen and Brewton also show that in this area, the Gulf shoreline of
Matagorda Peninsula retreated $156 \mathrm{~m}$ between 1856 and 1956. This rate, 1.6 $\mathrm{m} /$ year, is $40 \%$ greater than that estimated from long-term geological data.

\section{Southwestern matagorda peninsula}

Recession rates for a period of 1500 years can be estimated for southwestern Matagorda Peninsula where Pass Cavallo, a large active tidal pass, separates Matagorda Peninsula and Matagorda Island (Fig. 1). Matagorda Island is a wide sand-rich barrier which, unlike Matagorda Peninsula, has accreted throughout most of its history (Wilkinson, 1975). An accretionary history is reflected in the pronounced ridgeand-swale topography paralleling the modern shoreline along most of the island. Accretion of Matagorda Island was interrupted at one time by erosion which truncated ridges and swales along the island's eastern end. The causes of this erosion are not well understood. McGowen and Brewton (1975) suggested that erosion resulted from the closing of Pass Cavallo and smoothing of the Gulf shore by wave action (Fig. 4). Pass Cavallo was later reopened, and eastern
Matagorda Island began to accrete, sequentially developing its present form. This period of erosion and reprogradation is clearly revealed as a line of unconformity between the ridges and swales on the island's eastern end.

The period of erosion which smoothed the Gulf shoreline records the position of Matagorda Peninsula relative to Matagorda Island at the time the unconformity developed. A projection of the line of unconformity on Matagorda Island to the northeast, approximates the position occupied by Matagorda Peninsula at that time. A series of radiocarbon dates indicate an age of 1500 years B.P. for the unconformity of Matagorda Island (Wilkinson 1973). Comparison of the present shoreline of southwestern Matagorda Peninsula with the projected shoreline position 1500 years ago (Fig. 5) yields a recession rate of 1.3 $\mathrm{m} /$ year for this time interval.

Because of the construction of jetties along the Matagorda ship channel in 1965 , present erosion rates along this shoreline segment are highly variable. Data from the Galveston Office, U.S. Army Corps of Engineers indicates that between 1964 and $19711.46 \times 10^{6} \mathrm{~m}^{3}$ of







sand was removed from the beach and shoreface southwest of the south jetty of the ship channel. McGowen and Brewton (1975) reported historical recession rates from a point midway between the present ship channel and the southwestern end of Matagorda Peninsula of 1.9 $\mathrm{m} /$ year for the time period 1856-1956, which predates construction of the ship
Figure 6. Strike cross section across Southwestern Matagorda Peninsula, Pass Cavallo, and eastern Matagorda Islano showing the distribution of Holocene Facies. PA refers to the position of the paleoaxis of Pass Cavallo 3000 years ago. MA designates the modern axis of the pass.

Figure 7. Estimated erosion rate for Western Pass Cavallo. Long-term rate calculated by dividing the horizontal distance between the paleoaxis and the modern axis by 3000 years. Short-term erosion rate from McGowen and Brewton (1975).

the northeastern end of Matagorda Island and simultaneous deposition of sediment on the southwestern end of Matagorda Peninsula. Facies relationships of Matagorda Peninsula indicate that the axis of Pass Cavallo originally was 11.4 $\mathrm{km}$ northeast of its present position. This is the northeastern limit of shelly spitassociated sands, indicating that Pass Cavallo did not extend northeast of this point. Location of the paleoaxis of Pass Cavallo $11.4 \mathrm{~km}$ northeast of its present position coincides with a deep valley cut into Pleistocene sediments during Wisconsin glacial advances (Fig. 6). Morton and Donaldson (1973) also found that major tidal inlets are stabilized over older Pleistocene valleys on the southern Atlantic coast.

The time that Matagorda Island and Matagorda Peninsula originated is not accurately known. Several sources 
(Frazier 1974; Nelson and Bray 1970; Curray 1960) suggest that these barriers are no older than 3000 years. If an age of 3000 years can be assumed to be reasonably accurate, migration of Pass Cavallo $11.4 \mathrm{~km}$ in 3000 years yields an average annual erosion rate for northeastern Matagorda Island of $3.8 \mathrm{~m} /$ year (Fig. 7).

Short-term erosion rates for this coastal segment are fairly uniform along the western side of Pass Cavallo. McGowen and Brewton (1975) reported erosion rates directly southwest of Matagorda Peninsula of $5.5 \mathrm{~m} /$ year between 1856 and 1956 . This rate is $33 \%$ greater than that determined from long-term geologic data.

\section{Conclusions}

Data available for three areas along Matagorda Peninsula allow one to calculate short-term shoreline erosion, and to estimate long-term erosion rates. The differences between long-term (geological) and short-term (historical) rates for each area is remarkably consistant. In each of the three areas, short-term rates appear to be $30 \%$ to $40 \%$ greater than those for long-term intervals. Reasons for accelerated erosion rates are not precisely known. Increased erosion in the past century may be due to a variety of natural processes including those related (1) to climatic change which results in decreased sediment supply from fluvial systems updrift, (2) to increased water depths along Matagorda Peninsula by removal of shoreface sediment, (3) to increased rates of dune development which removes sand from the littoral areas, or (4) to decreased sediment supply by fluvial sources as streams decrease their gradients by valley down-cutting. With data available at present, it is not possible fully to evaluate the significance of each process. Whereas possible reasons for the apparent increases are numerous, more rapid recession during the past century suggests that changes may be man-induced.

These artificial modifications include such activities as (1) construction of jet- ties and seawalls, (2) subsidence due to groundwater withdrawal, and (3) damming the major sand-contributing rivers. It is difficult at this point to ascertain the future impact of man-made modifications on the coastal zone. Clearly, recession has been a natural process in these three areas for a long time. Recession will undoubtedly continue in these areas, and may accelerate as man's activities continue to interrupt natural sediment dispersal systems. Much additional data on long-term rates and processes are needed before the impact of these modifications can be fully evaluated. However, the long-time data available for this area suggests that short-term recession rates may represent conditions of accelerated erosion, and indicate that this trend toward more rapid recession may continue.

\section{ACKNOWLEDGMENTS}

The paper was read and criticized by Erwin Seibel, Assistant Director, Sea Grant Program, The University of Michigan, and C. G. Groat, Acting Director, Bureau of Economic Geology, The University of Texas at Austin. Support for portions of this work were provided by a Faculty Research Grant from the Rackham School of Graduates Studies, The University of Michigan. We thank the Galveston Office of the U.S. Army Corps of Engineers, who provided several logs of borings made in southwestern Matagorda Peninsula. Publication is authorized by the Director, Bureau of Economic Geology, The University of Texas at Austin.

\section{REFERENCES}

Curray, J. R., 1960, Sediments and history of Holocene transgression, continental shelf, northwest Gulf of Mexico, in Shepard, F. P., F. B. Pitleger, and T. H. van Andel, eds., Recent sediments, northwest Gulf of Mexico: Tulsa, Okla., Am. Assoc. Petroleum Geologists, p. $221-266$.

Frazier, D. E., 1974, Depositional-episodes: their relationship to the Quaternary stratigraphic framework in the northwestern portion of the Gulf Basin: Univ. Texas, Austin, Bur. Econ. Geol. Circ. 74-1, $28 \mathrm{p}$.

McGowen, J. H., and J. L. Brewton, 1975 , Historical changes and related coastal processes, Gulf and mainland shorelines, Matagorda Bay area, Texas: Univ. Texas, Austin, Bur. Econ. Geol., Spec. Pub. $72 \mathrm{p}$.

Morton, R. A., and A. C. Donaldson, 1973, Sediment distribution and evolution of tidal deltas along a tide-dominated shoreline, Washapreague, Virginia: Sed. Geology, v. 10 , p. 285-299.

Nelson, H. F., and E. E. Bray, 1970, Stratigraphy and history of the Holocene sediments in the Sabine, High Island area, Gulf of Mexico, in Morgan, J. P., and R. H. Shaver, eds., Deltaic sedimentation, modern and ancient: Soc. Econ. Paleontologists and Mineralogists Spec. Pub. No. 15. p. $48-77$.

Shepard, F. P., 1973, Submarine geology: New York, Harper and Row, $517 \mathrm{p}$.

Shepard, F. P., and D. G. Moore, 1960, Bays of central Texas Coast, in Shepard, F. P., F. B. Pitleger, and T. H. van Andel, eds., Recent sediments, northwest Gulf of Mexico: Tulsa, Okla. Am. Assoc. Petroleum Geologists, p. 117-152.

Wilkinson, B. H., 1973, Matagorda Island: The evolution of a Gulf coast barrier complex: Univ. Texas, Austin, unpub. Ph.D. dissertation, $178 \mathrm{p}$.

- 1975, Matagorda Island Texas: The evolution of a Gulf coast barrier complex: Geol. Soc. America Bull., v. 86, 959-967. 